\title{
Metamorphic reworking of a high pressure-low temperature mélange along the Motagua fault, Guatemala: A record of Neocomian and Maastrichtian transpressional tectonics
}

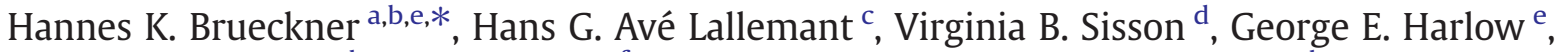 \\ Sidney R. Hemming ${ }^{\text {b }}$, Uwe Martens ${ }^{\text {f }}$, Tatsuki Tsujimori ${ }^{\mathrm{g}}$, Sorena S. Sorensen ${ }^{\mathrm{h}}$ \\ a School of Earth and Environmental Sciences, Queens College and The Graduate Center, CUNY, Flushing, NY 11367, USA \\ ${ }^{\mathrm{b}}$ Lamont-Doherty Earth Observatory, Columbia University, Palisades, NY 10964, USA \\ c Department of Earth Science, Rice University, Houston, TX, 77005, USA \\ ' Geosciences Department, University of Houston, Houston, TX, 77204, USA \\ e Department of Earth and Planetary Sciences, American Museum of Natural History, New York, NY 10024, USA \\ ${ }^{\mathrm{f}}$ Department of Geological and Environmental Sciences, Stanford University; Stanford, CA 94305, USA \\ ${ }^{g}$ The Pheasant Memorial Laboratory for Geochemistry and Cosmochemistry, Institute for Study of the Earth's Interior, Okayama University, Misasa, Tottori 682-0193, Japan \\ ${ }^{\mathrm{h}}$ Department of Mineral Sciences, National Museum of Natural History, Smithsonian Institution, Washington, DC 20560, USA
}

\section{A R T I C L E I N F O}

\section{Article history:}

Received 2 December 2008

Received in revised form 22 April 2009

Accepted 22 April 2009

Available online 27 May 2009

Editor: T.M. Harrison

Keywords:

Sm-Nd geochronology

HP/LT eclogites

strike-slip and subduction zone processes

oblique collisional tectonics

\begin{abstract}
A B S T R A C T
The Guatemala suture zone is a major east-west left-lateral strike slip boundary that separates the North American and Caribbean plates in Guatemala. The Motagua fault, the central active strand of the suture zone, underwent two major collisional events within a system otherwise dominated by strike-slip motion. The first event is recorded by high-pressure/low temperature (HP/LT) eclogites and related rocks that occur within serpentinites both north and south of the Motagua fault. Lawsonite eclogites south of the fault are not significantly retrograded and give ${ }^{40} \mathrm{Ar} /{ }^{39} \mathrm{Ar}$ ages of $125-116 \mathrm{Ma}$ and $\mathrm{Sm}-\mathrm{Nd}$ mineral isochrons of 144-132 Ma. Eclogites north of the fault give similar Sm-Nd isochron ages (131-126 Ma) but otherwise differ in that they are strongly overprinted by a lower pressure assemblage and, along with associated HP/LT rocks, give much younger ${ }^{40} \mathrm{Ar} /{ }^{39} \mathrm{Ar}$ ages of $88-55 \mathrm{Ma}$ indicating a later amphibolite facies metamorphic event. We propose therefore that all serpentinite hosted eclogites along the Motagua fault formed at essentially the same time in different parts of a laterally extensive Lower Cretaceous forearc subduction system, but subsequently underwent different histories. The southern assemblages were thrust southwards (present coordinates) immediately after HP metamorphism whereas the northern association was retrograded during a later collision that thrust it northward at ca. $70 \mathrm{Ma}$. They were subsequently juxtaposed opposite each other by major strike slip motion. This model implies that the HP rocks on opposing sides of the Motagua fault evolved along a plate boundary that underwent both dip slip and strike slip motion throughout the Late Cretaceous as a result of oblique convergence. The juxtaposition of a convergent and strike slip system means that HP/LT rocks within serpentinites can be found at depth along much of the modern Guatemala suture zone and its eastward extension into the northern Caribbean. Both sets of assemblages were exhumed relatively recently by the uplift of mountain ranges on both sides of the fault caused by movement along a restraining bend. Recent exhumation explains the apparently lack of offset of surface outcrops along a major strike slip fault.
\end{abstract}

(C) 2009 Elsevier B.V. All rights reserved.

\section{Introduction}

Serpentinite belts exposed on land and containing high pressure/ low temperature (HP/LT) metamorphic rocks were interpreted originally as occupying the suture zone between two tectonostratigraphic terranes (Hess, 1965; Maekawa et al., 2004) and to reflect the closure

\footnotetext{
* Corresponding author. Lamont-Doherty Earth Observatory, Columbia University, Palisades, NY 10964 USA. Tel.: +1845 3658388

E-mail address: hannes@ldeo.columbia.edu (H.K. Brueckner).
}

of ocean basins as part of the Wilson Cycle (Wilson, 1960). Most sutures were assumed to be perpendicular to convergent directions since major dip slip motion is required to form HP rocks. However, many modern compressional terrane boundaries are not perpendicular to convergent directions, but oblique and so older serpentinite belts may also reflect oblique convergence at the time they formed. We propose that two HP/LT bearing serpentinite belts that occur parallel to each other across the Motagua fault in Guatemala, Central America are examples of a suture that evolved through oblique convergence. ${ }^{40} \mathrm{Ar} /{ }^{39} \mathrm{Ar}$ ages from $\mathrm{HP} / \mathrm{LT}$ rocks within the serpentinites (Harlow et al., 2004) give Early Cretaceous age south of the fault 
and Late Cretaceous age north of the fault, which indicate that the exposed serpentinites were juxtaposed by strike slip movement along the Motagua fault. Here we present Sm-Nd geochronology from eclogites that show the original recrystallization of the eclogites on both sides occurred at the same time during the Early Cretaceous, which indicates that the two belts shared an early history of convergence and subduction. A common early history, but a different subsequent history involving both large magnitude strike slip and dip slip movement suggests that the Motagua fault is part of a boundary that has undergone oblique convergence since the early Cretaceous.

\section{Regional setting}

The Guatemala suture zone is presently part of a major left lateral strike slip boundary between the North American plate to the north (locally known as the Maya block) and Caribbean plate (locally, the Chortís block) to the south (Fig. 1). The present displacement rate along the Guatemala suture zone is estimated at about $21 \mathrm{~mm} /$ year (DeMets et al., 2007) and the total displacement since the Early Eocene is estimated to be $\geq 1100 \mathrm{~km}$ (Rosencrantz and Mann, 1991). The three major strands of the Guatemala suture zone are, from north to south, the Polochíc, Motagua, and Jocotán faults. The Motagua fault (a.k.a. San Agustín-Motagua-Cabañas-Jubuco and Cuyamel faults) runs ENE-WSW more or less along the Motagua River and is sometimes considered the actual present-day boundary between the Maya block and the Chortís block (however, see Ortega-Gutiérez et al., 2007 for a more complex interpretation of the boundary). Lithologic units on opposite sides are, with the exception of serpentinites and related rocks, quite different (Martens et al., 2007a,b), consistent with considerable lateral displacement along the Motagua fault. The units in the Maya block include the Chuacús metamorphic complex, recently shown to include eclogitic lenses that record a Late Cretaceous HP/HT event (Ortega-Gutiérrez et al., 2004, Martens et al., 2007b, 2009), Paleozoic sedimentary rocks of the Santa Rosa Group, low-grade metasediments (white mica-chlorite schists, quartzite, and minor marble) associated with antigorite schist/mélange and deformed granites. The Chortís block contains the greenschist-facies San Diego phyllite, the amphibolite-facies Las Ovejas complex, and relatively undeformed granitoids. Numerous $\mathrm{U}-\mathrm{Pb}$ zircon ages from granites and their host gneisses north of the fault give Late Proterozoic (Grenville), Carboniferous, and Triassic ages as well as a metamorphic event at ca. $70 \mathrm{Ma}$ (Martens et al., 2007a,b, 2009). Ages from gneisses and granitoids south of the fault are sparse and so cannot be compared with those to the north.

Major faults associated with the Motagua fault are shown in Fig. 1. They are ENE-WSW trending north-vergent thrust faults in the north, south-vergent thrust faults in the south, and steeply dipping strike slip faults in the middle. Mesoscopic structures are generally related to motions along the large faults. Kinematic indicators in metamorphic rocks, both north and south of the Motagua fault, indicate left-lateral strike slip and dip slip movement. The very strong stretching lineation in these rocks is subhorizontal and EW-trending indicating considerable lateral displacement. A less developed NS-trending lineation indicates some strain or displacement occurred to the north and/or south (Francis, 2005; Francis et al., submitted for publication), consistent with the presence of thrust faults and eclogite-facies rocks. ${ }^{40} \mathrm{Ar} /{ }^{39} \mathrm{Ar}$ dates indicate these displacements occurred throughout the Cretaceous (Harlow et al., 2004). NE and NW striking high angle faults within the Motagua Valley are related to the generation of pull-apart basin filled with Tertiary sediments and indicate that movement since the Late Cretaceous was largely strike slip. Late high angle normal faults occur in the mountains on both sides of the Motagua fault that dip steeply towards the Motagua valley with downward dip slip motion of the blocks closest to the river. These faults are probably related to the uplift of mountain ranges on both sides of the fault.

Serpentinite bodies and serpentinite mélanges occur throughout the Guatemala suture zone (see inset in Fig. 1). However the antigorite serpentinites that contain HP/LT eclogites, jadeitites and other unusual rocks appear to be restricted to both sides of the Motagua fault (Harlow et al., 2003, 2004; Tsujimori et al., 2006a,b; Sorensen et al., 2006). The distribution of these eclogite-bearing serpentinites along the Motagua fault (Fig. 1) seems to create a dilemma since the apparent offset between the two sides based on surface exposure could range from 0 to, at most, $80 \mathrm{~km}$ (20 km according to Donnelly et al., 1990). The serpentinites should have been displaced laterally by much larger distances relative to each other if the Motagua fault is a major active strand of the Guatemala strike slip system. Harlow et al. (2004) addressed the apparent lack of offset by proposing that the eclogite bearing serpentinites, though superficially similar, are of different age and originated more than $1000 \mathrm{~km}$ apart and then were juxtaposed by strike slip motion along the Motagua suture zone. This coincidental juxtaposition seemed tenable because $\mathrm{Ar}-\mathrm{Ar}$ ages from phengite and other phases were different on the two sides: ca. $60 \mathrm{Ma}$ to the north and ca. $125 \mathrm{Ma}$ to the south. Juxtaposition of HP/LT terranes that formed at different times seemed reasonable.

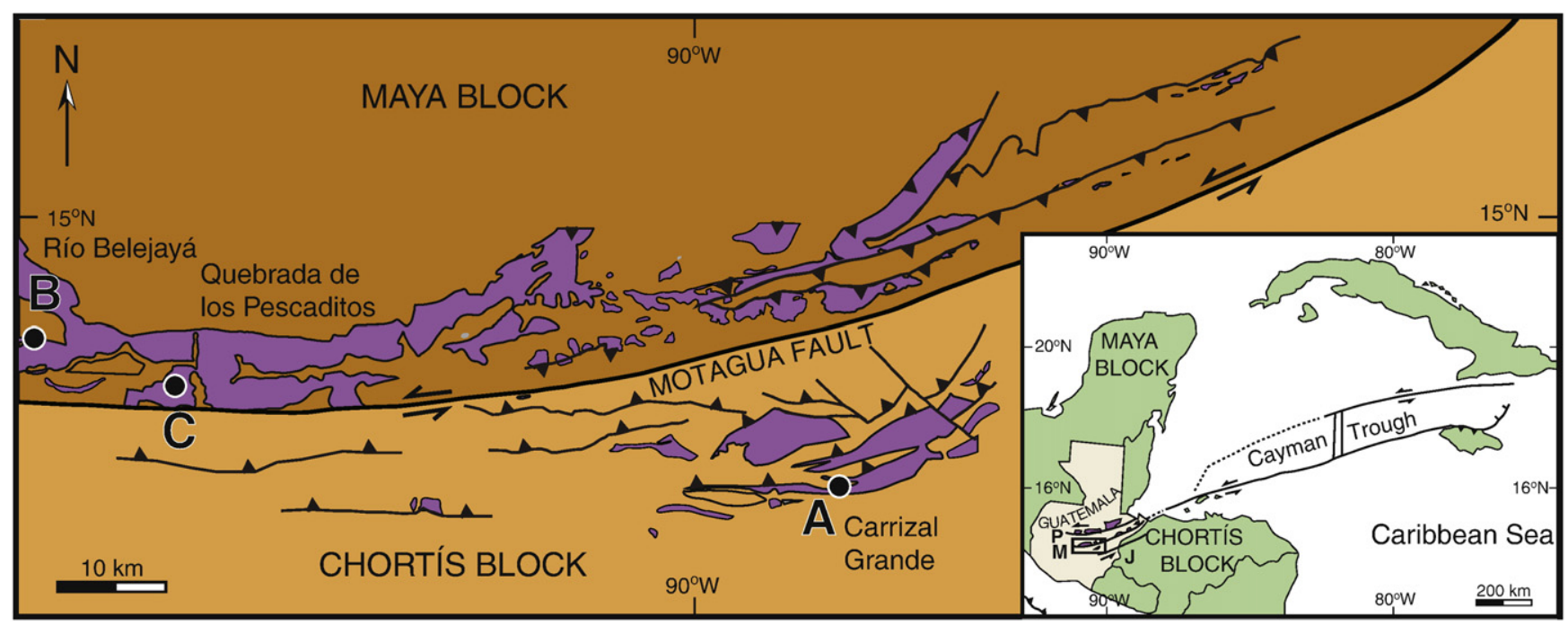

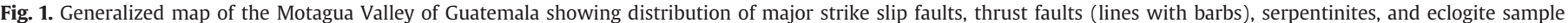

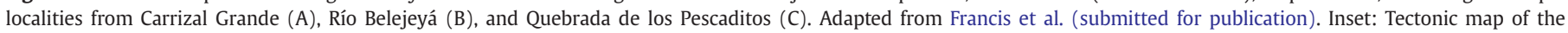
northwestern Caribbean and location of the study area (rectangle). Faults are P - Polochíc, M - Motagua, and J - Jocotán. Together they comprise the Guatemala suture zone. 
However the results that will be presented below indicate that both suites of HP/LT rocks formed at the same time and so the juxtaposition model would require that two HP/LT terranes of identical age were juxtaposed by large-scale strike slip displacements. We propose a geometry that can explain this apparent conundrum further along in this manuscript.

\section{Serpentinites}

All serpentinites and serpentinite mélanges are tectonic slices bounded by thrust faults or by steep E-W strike slip faults (Francis, 2005). The thrust faults have been interpreted as "flower structures" (Beccaluva et al., 1995; Giunta et al., 2002), but the cross-cutting strike slip faults and dip slip faults discussed above suggest that they are not contemporaneous with Tertiary strike slip motion along the Motagua ault (McBirney, 1963; McBirney et al., 1967; Donnelly et al., 1990; Francis, 2005; Tsujimori et al., 2006a; Francis et al., submitted for publication). The serpentinites that contain HP/LT blocks occur immediately north and south of the Motagua fault are antigorite dominant and heavily sheared. Antigorite serpentinites south of the fault are associated with low-grade siliciclastic rocks and minor basalt (including pillow basalt) and are considered components of the El Tambor complex. Radiolaria from cherts within the El Tambor have a Late Jurassic age (Chiari et al., 2002). The antigorite serpentinites north of the Motagua fault are presumably of similar age, but their relationship to the El Tambor complex is less clear. Lower temperature chrysotile-lizardite-bearing serpentinites occur over a wider area in the Guatemala suture zone ranging from selvages in the El Tambor formation just south of the Motagua fault to the Juan de Paz serpentinite (Muller, 1979) just north of the Motagua fault and the extensive Santa Cruz and Baja Verapaz ultramafic complexes further north of the Motagua fault. These serpentinites contain no HP/LT blocks though some contain some amphibolites. They are assigned an Early Cretaceous age based on fossils from the Santa Cruz serpentinites (Rosenfeld, 1981). It appears that low temperature serpentinites and associated ophiolitic rocks north of the Motagua fault, particularly those adjacent to the Polochíc fault, are younger (Early Cretaceous) than the antigorite serpentinites of the El Tambor in the immediate vicinity of the fault (Late Jurassic).

\section{Eclogites and associated rocks}

Eclogite sample localities are shown in Fig. 1. Eclogites, jadeitites, albitites, and other HP/LT rocks are usually found as boulders in the rivers that drain antigorite-bearing serpentinite bodies (Fig. 1) and flow into the Motagua River. Eclogites south of the Motagua fault were collected from river drainages below the village of Carrizal Grande. Eclogite north of the Motagua fault were collected along Quebrada de Los Pescaditos about $5 \mathrm{~km}$ south of San Buenaventura and from Río Belejeyá about $5 \mathrm{~km}$ west of Granados. Detailed petrography of these samples is presented in Appendix A or for samples ACG-01 and ACG-17, by Tsujimori et al. (2006a,b).

Trace and major element geochemistry and $\mathrm{Li}, \mathrm{Sr}$, and Nd isotopic patterns of eclogites, peridotites, serpentinites, and jadeitites indicate that the eclogite protoliths from both sides of the fault originated at a mid-ocean ridge and subsequently were metamorphosed and metasomatized in a mantle wedge above a subduction zone (Beccaluva et al., 1995; Sorensen et al., 2006; Simons et al., submitted for publication). Petrographic and thermobarometric studies of the eclogite mineral assemblages indicate they are of the "blueschist" or "Franciscan" type, typical of subduction complexes (Ernst, 1988). Eclogites south of the Motagua fault range from pristine to mildly retrograded. They contain garnet + omphacite $( \pm$ jadeite $)+$ lawsonite (several generations) + rutile \pm quartz \pm phengite \pm apatite \pm titanite \pm chlorite \pm sulfide and show prograde metamorphic textures. $P-T$ equilibration conditions are estimated at
$300-480{ }^{\circ} \mathrm{C}$ and 1.1 to $2.6 \mathrm{GPa}$ (Tsujimori et al., 2006a). Retrograde features, where developed, occur as reversely zoned garnet rims associated with secondary omphacite + lawsonite + titanite \pm phengite \pm glaucophane \pm albite + quart \pm apatite \pm sulfide assemblages estimated to have formed at $P \approx 1.4 \mathrm{GPa}$ and $T \approx 400{ }^{\circ} \mathrm{C}$ (Tsujimori et al., 2005, 2006a). An even younger blueschist overprint consists of glaucophane + lawsonite + chlorite + titanite + quartz \pm phengite. Tsujimori et al. (2006a) estimate that the $P-T$ trajectory of these assemblages lies along a geotherm of $\approx 5^{\circ} \mathrm{C} / \mathrm{km}$, comparable to the coldest geotherms from subduction zones worldwide.

The metabasites north of the Motagua fault zone are mostly garnet amphibolites that contain clinozoisite and pargasite/magnesio-hornblende amphibole with rare omphacite and abundant clinozoisite and amphibole inclusions in garnet. The rare omphacite inclusions suggest initial eclogite-facies crystallization. The clinozoisite and amphibole inclusions suggest a later high pressure amphibolite facies metamorphism with a garnet crystallization temperature of $500-600{ }^{\circ} \mathrm{C}$ at a pressure of 1.2-1.5 GPa (Harlow et al., 2008). An even later assemblage of clinozoisite + albite + quartz + actinolitic amphibole indicates a subsequent greenschist overprint. True eclogite was found by us recently in the western reaches of the mélange zone north of the Motagua fault (Fig. 1) though they contain primary clinozoisite instead of lawsonite. The primary assemblage of garnet + omphacite, + phengitic muscovite + rutile + clinozoisite, + glaucophanic to pargasitic amphibole \pm quartz suggests a higher temperature $\left(500-600{ }^{\circ} \mathrm{C}\right)$ of formation than the southern eclogites. This eclogite assemblage is moderately to strongly overprinted by a clinozoisite + actinolitic amphibole \pm paragonite \pm biotite + titanite + albite + quartz \pm apatite \pm sulfides assemblage suggesting subsequent recrystallization at comparable temperatures ( $T \approx 550-600{ }^{\circ} \mathrm{C}$, Tsujimori et al., 2004; Harlow et al., 2008). The secondary assemblages were initially interpreted as retrograde assemblages formed during decreasing pressure and temperature conditions (Harlow et al., 2004), but are now believed to have formed during a later metamorphism. Thus the northern eclogites underwent a later greenschist to amphibolite facies recrystallization event whereas the southern eclogites did not. These distinct $P-T$ histories are supported by ${ }^{40} \mathrm{Ar} /{ }^{39} \mathrm{Ar}$ phengite and/or amphibole dates with southern eclogites giving ages of 125-116 Ma while northern eclogites and associated rocks give ages of 88-55 Ma (Harlow et al., 2004).

\section{Results}

Sm-Nd analytical procedures are described in Appendix B and the data are presented and discussed in detail in Appendix C. Six of the most meaningful results (out of eight samples analyzed) are plotted on Fig. 2. The Sm-Nd ages considered reliable have low error (low MSWD), contain more than one garnet analysis, or an analysis of an additional phase besides garnet and clinopyroxene (i.e., phengite, apatite). The most precise ages from south of the Motagua fault are the $132.1 \pm 6.5 \mathrm{Ma}$ age from MVE02-6-3 (Fig. 2A) and the 143.9土 $9 \mathrm{Ma}$ from ACG-03 (Fig. 2B). The latter age becomes $140.6 \pm 3.4 \mathrm{Ma}$ $(M S W D=0.54)$ if the first garnet analysis (64 ratios, low intensity) is excluded. This age is considered relatively robust, despite the lack of a whole rock analysis because three phases were analyzed. The results from sample MVE02-14-6 are more equivocal. Five garnet separates were analyzed with each analysis plotting at a different location (Fig. 2C). The resultant scatterchron (MSWD $=83$ ) age of $133 \pm 14$ Ma is obviously an average. The final two garnet analyses attempted to separate and date the darker garnet core from the lighter rim by color. However the pink rim ( +2 clinopyroxenes and 2 whole rock samples) gives an older age (130.2 $\pm 1.6 \mathrm{Ma})$ than the redder core $(123.8 \pm 1.9 \mathrm{Ma})$ and the oldest age is obtained from the second analysis of a bulk garnet sample $(144.7 \pm 1.6 \mathrm{Ma})$. The scattered ages are provisionally interpreted as reflecting the span of garnet growth, suggesting this growth began at ca. $145 \mathrm{Ma}$ and ended roughly twenty million years later at ca. $124 \mathrm{Ma}$. 

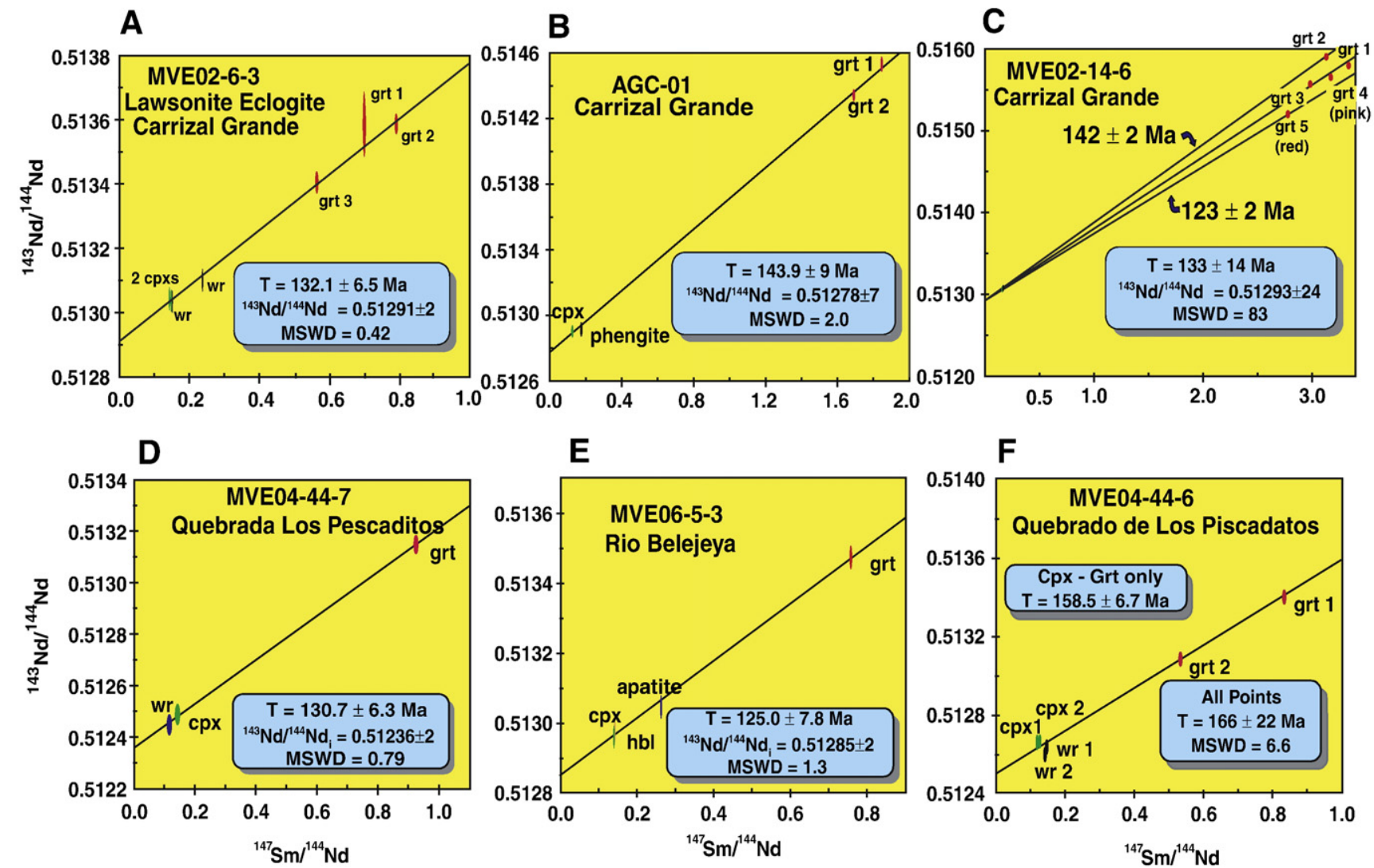

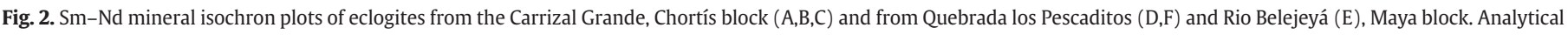
details are presented in Appendix B.

The ages considered reliable from north of the fault are from two relatively weakly overprinted eclogites. They are $130.7 \pm 6.3 \mathrm{Ma}$ from MVE04-44-7 from Quebrada de Los Pescaditos (Fig. 2D) and the $125.0 \pm 7.8 \mathrm{Ma}$ age from MVE06-5-3 from Río Belejeyá (Fig. 2E). The $125.0 \pm 7.8 \mathrm{Ma}(\mathrm{MSWD}=1.3)$ age from Río Belejeyá (Fig. 2E) is considered particularly robust. Analysis of the quartz- and albiterich fraction yielded a point that occupies an intermediate position on the mineral isochron diagram, something that is rare in eclogite analyses and gives confidence in the isochron. The fraction probably contained hydroxylapatite based on its abundance in thin section (Appendix A).

Sample MVE04-44-6 from Quebrada de Los Pescaditos generated an age of $166 \pm 22 \mathrm{Ma}$ (Fig. $2 \mathrm{~F})$. The scatter $(\mathrm{MSWD}=6.6)$ is produced by the positions of two clinopyroxenes above and two whole rocks below the best-fit line. We suspect fluid-introduced crustal $\mathrm{Nd}$ lowered the ${ }^{143} \mathrm{Nd} /{ }^{144} \mathrm{Nd}$ ratios of the whole rock and, to a lesser extent, the clinopyroxenes, thereby producing scatter and steepening of the best-fit line to produce an unrealistic old age.

The four most credible ages are essentially Early Cretaceous (Neocomian) and give an average of $132 \mathrm{Ma}$ and a weighted average of $136 \pm 11$ Ma. However, all ages probably "average" a period of eclogitefacies recrystallization that, based on the age span for garnets from MVE02-14-6 (Fig. 2C), may have lasted 20 million years or more. The ages appropriately post-date the formation of the youngest ocean floor lithology found south of the Motagua fault, the Late Jurassic El Tambor ophiolite (Chiari et al., 2002), suggesting similar age crust was subducted to form the eclogites. The Sm-Nd ages are also consistent with the ${ }^{40} \mathrm{Ar} /{ }^{39} \mathrm{Ar}$ ages of $116-125 \mathrm{Ma}$ determined from the southern eclogites, but are much older that the ${ }^{40} \mathrm{Ar} /{ }^{39} \mathrm{Ar}$ ages of $88-55 \mathrm{Ma}$ from eclogites and related rocks north of the fault (Harlow et al., 2004).

\section{Discussion}

\subsection{An apparent conundrum resolved}

The Motagua fault is active today based on offset terraces and the 1976 magnitude 7.5 earthquake (Schwartz et al., 1979). Nevertheless, Donnelly et al. (1990) estimated the total displacement along the Motagua fault as only $20 \mathrm{~km}$ appearing to create a conundrum of why large scale strike slip motion along the Guatemala suture zone ( $\geq 1100 \mathrm{~km}$ according to Rosencrantz and Mann, 1991) did not send these HP/LT rocks hundreds of kilometers in opposite directions. The solution may be that the Motagua fault became the active strand of the Guatemala suture zone relatively recently, consistent with recent plate tectonic reconstructions that show the Motagua fault was not active until the Early Pliocene, $4 \mathrm{Ma}$ ago, and that most of the Post-Cretaceous motion along the present Guatemala suture zone was carried by the Polochíc and Jocotán Faults (Rogers and Mann, 2007). If the estimated $\approx 21 \mathrm{~mm} / \mathrm{yr}$ displacement rate of the Guatemala suture zone occurred solely along the Motagua fault for only the last $4 \mathrm{Ma}$, the total displacement of $\approx 84 \mathrm{~km}$ is greater than the apparent displacement of $20 \mathrm{~km}$ estimated by Donnelly et al. (1990), but within the displacements inferred from the outcrop distribution in Fig. 1.

However, as already noted, stretching lineations in mylonites are parallel to the Motagua fault suggesting significant long-term leftlateral displacement under metamorphic conditions (McBirney, 1963; McBirney et al., 1967; Donnelly et al., 1990; Francis, 2005; Tsujimori et al., 2006a,b; Francis et al., submitted for publication). In addition, the Motagua fault is associated with trans-extensional basins containing the Eocene or older beds of the Subinal Formation suggesting left-lateral movement for at least 30-40 Ma. The most important observation, 
however, is that the $P-T$ - $t$ histories of the eclogites on opposite sides of the fault are significantly different, despite forming initially more or less at the same time. The lower Cretaceous history differs in that the southern eclogites record lawsonite eclogite formation along a very cold subduction trajectory $\left(\sim 5^{\circ} \mathrm{C} / \mathrm{km}\right)$ whereas the northern eclogites record a warmer lawsonite-free trajectory $\left(\sim 7^{\circ} \mathrm{C} / \mathrm{km}\right)$. But the most striking difference is the ca. 70 Ma greenschist/amphibolite-facies overprint recorded by the northern eclogites, but not the southern eclogites. These observations argue that eclogites from different initial locations were indeed juxtaposed by large-scale strike slip motion as originally suggested by Harlow et al. (2004). But the question remains as to why HP/LT terranes, initially far apart and with different histories, would have a common Early Cretaceous origin.

This dilemma is resolved if the Guatemala suture zone, and the Motagua fault in particular, follow a Lower Cretaceous convergent suture for a large portion of its length. The implication of this geometry is that eclogite-bearing serpentinites could occur at depth along much of the suture zone, but the terranes on opposite sides would have undergone different histories as a result of different initial positions in the suture followed by large lateral displacements. This geometry is not unique. For example, Cordilleran terranes, including convergent system such as the Franciscan Formation, underwent large-scale strike slip displacements (1000-3000 km) parallel to the western margin of North America throughout Late Jurassic, Cretaceous and Tertiary time (e.g., Avé Lallemant and Oldow, 1988; Umhoefer and Dorsey, 1997). Thus the terranes on opposite sides of the Motagua fault could have been originally from the same Lower Cretaceous subduction system, but were positioned far apart along strike in areas where one terrane underwent a subsequent Late Cretaceous event whereas the other did not.

\subsection{Recent exhumation}

An additional consequence of this geometry is that HP/LT terranes could be exposed on either side or both sides of the fault at any time at any place along the length of the Motagua fault given the operation of a suitable exhumation mechanism. The serpentinites and serpentinite mélanges shown on Fig. 1 occur amidst two ranges; the Sierra de Las Minas range to the north, uplifted to about $3000 \mathrm{~m}$ above the Motagua Valley and an unnamed range to the south that is uplifted to an average of $1500 \mathrm{~m}$ above the Motagua Valley (Edwards et al., 2000; Rogers et al., 2002). Both ranges are undergoing active uplift today as a result of transpression along the Motagua fault (Rogers et al., 2002), which shows a change in trend from ENE-WSW in the east to E-W in the area of the mountain ranges (Fig. 1). Fission track dating suggests these ranges began uplift between 55-31 and 24-16 Ma ago for the northern and southern ranges respectively (Francis, 2005). The exposure of the serpentinites and their cargo of HP/LT rocks is thus a recent and spatially restricted phenomenon caused by the local existence of a restraining bend. Their recent exhumation on both sides of the fault explains their apparent lack of large-scale displacement along a fault system that has undergone major strike slip motion. Presumably continued strike slip motion on the Motagua fault will send the two LT/HP terranes in opposite directions and create a significant offset well into the future. If our suggestion is correct, similar eclogite-bearing antigorite serpentinites may occur along much of the Motagua fault, but are still at depth awaiting an exhumation mechanism.

\subsection{A strike slip/convergent tectonic model}

There is strong evidence that the Chortís block originated from the west coast of Mexico and was translated towards the southeast along left lateral strike slip faults (Pindell, 1994; Mann, 2007; Pindell and Kennan, in press). Yet, the presence and metamorphic ages of HP/ LT eclogites within serpentinites of the Motagua fault require two convergent events as well; Early Cretaceous subduction of the PaleoPacific beneath western Mexico followed roughly 60 my later by a collision of the Maya block with another terrane. Thus, any tectonic model for the evolution of these rocks requires synchronous or alternating strike slip motion and convergence. We propose a synchronous model where oblique convergence of the Farallon plate with western Mexico resulted in the formation of both a left-lateral strike slip system (the Paleo-Motagua fault zone) parallel to the plate boundary and a spatially coincident subduction system with motion normal to the plate boundary (Fitch, 1972; Avé Lallemant and Guth, 1990). Thus the event that initially crystallized the HP/LT eclogites of the Motagua fault (Fig. 3A) during the Early Cretaceous involved the subduction of the Farallon plate beneath western Mexico, as shown in Fig. 3A, or possibly a terrane outboard of Mexico. A discrete collision between the Chortís block and western Mexico is not required and portions of the Farallon oceanic crust may have survived locally along strike. The Upper Jurassic El Tambor ophiolite complex represents obducted fragments of the Farallon plate, whereas the HP/LT eclogites represent deeply subducted fragments of the Farallon plate that underwent metamorphism typical of "Franciscan"-type eclogites as they mixed with serpentinites created by the aqueous metasomatism of the mantle wedge above the subduction zone (Fig. 3A). The different Early Cretaceous $P-T$ gradients of the northern versus southern eclogites suggest that they were generated in different places within the subduction complex and therefore underwent different $P-T$ trajectories (Gerya et al., 2002; Gorczyk et al., 2007). A subduction complex can be active for many tens of millions of years explaining, the $>20$ million year interval of eclogite growth inferred from some of the Sm-Nd dates presented in Fig. 2 . The $P-T$ and chemical history within an accretionary prism can be quite complex as the eclogite protoliths are churned to different levels below the mantle wedge and as fluids of different compositions flux through at different times (Krebs et al., 2008).

A portion of this accretionary prism, with its cargo of serpentinites, eclogites, and other HP rocks, was thrust over the leading edge of the Chortís block (Fig. 3A) and isolated from subsequent convergent tectonics. The northward dip of thrust faults on the Chortís block is consistent with this model (Fig. 1). The apparent paucity of deep sea lithologies normally associated with accretionary prisms may require a system relatively starved of sediments, similar to those that occur today west of the Andes of South America. Alternatively, much of the accretionary prism may have been subducted (e.g., von Huene et al., 2004; Scholl and von Huene, 2007).

Subsequently, new oceanic crust was generated between the Chortís block and western Mexico as a result of rotation and left lateral translation along the Paleo-Motagua fault zone forming, in effect, a transextensional marginal basin that widened for much of the Cretaceous (Francis, 2005). The existence of a basin that floored by younger crust is supported by the Early Cretaceous fossils found within the Santa Cruz and Juan de Paz ophiolites (Muller, 1979; Rosenfeld, 1981) north of the Motagua fault. This new crust may or may not have been bordered by remnants of the older Farrallon plate. The evolution of this ocean system changed from spreading to contraction some time before the end of the Cretaceous culminating in the oblique collision at ca. 70 Ma of the southern end (present coordinates) of the Maya block or perhaps a sliver of this block, now called the Chuacús complex, with a southern terrane that presently has moved well to east of the position that Chortís block presently occupies across the Motagua fault. This shifted terrane presumably is now part of the Nicaraguan Rise or the Great Antilles Arc (Martens et al., 2009).

The second oblique collision is given substantial credibility by recently discovered $\mathrm{HP} / \mathrm{HT}$ crustal eclogites within the crystalline Chuacús complex of the Maya block (Ortega-Gutiérrez et al., 2004; Martens et al., 2007a,b, 2009) indicating the Chuacús complex was subducted $60 \mathrm{~km}$ into the mantle in an Himalayan style collision. The age of this crustal-subduction event is dated at 65 to $70 \mathrm{Ma}$ based on U-Pb zircon ages from Chuacús gneisses (Martens et al., 2007a,b), a $68 \pm 8 \mathrm{Ma} \mathrm{U}-\mathrm{Pb}$ age from a zircon rim within eclogite (Martens et al., 2008) and a ca. $76 \mathrm{Ma}$ Sm-Nd mineral isochron from an eclogite 


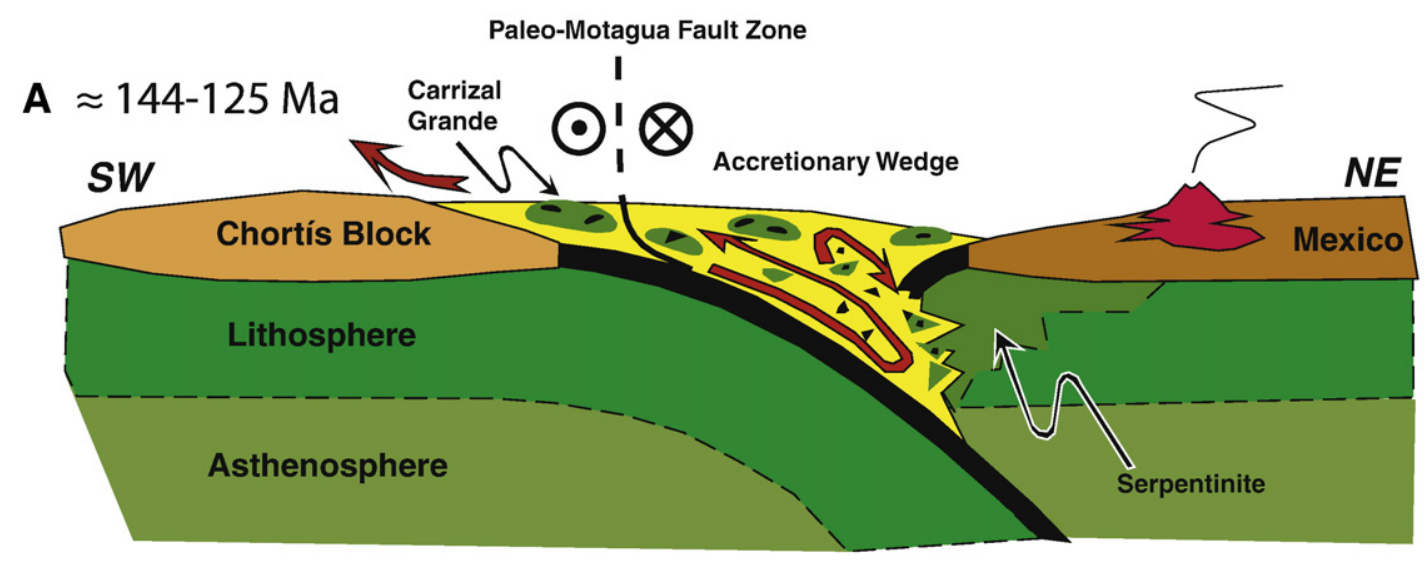

$\mathrm{B} \approx 70 \mathrm{Ma}$

Paleo-Motagua Fault Zone

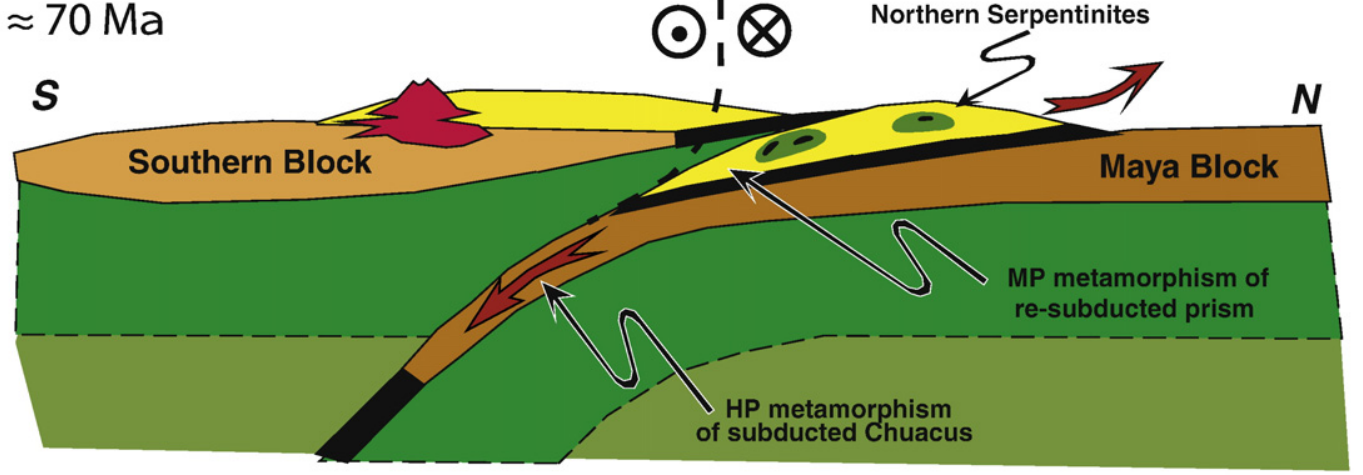

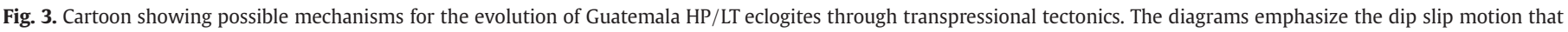

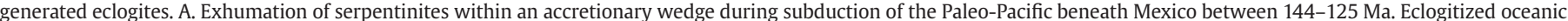

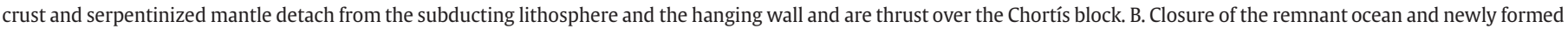

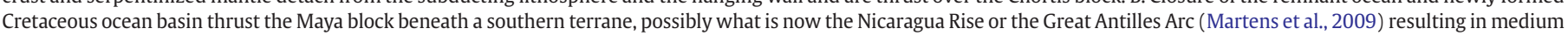

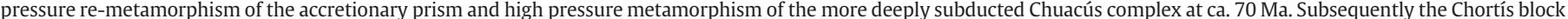

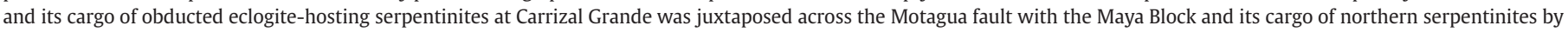
large scaled strike slip motion along the Paleo-Motagua fault zone and, later, along the Motagua fault.

(Martens et al., 2009). These ages overlap the Ar-Ar ages of 88-55 Ma from eclogites within the northern block serpentinites. It seems inescapable that the synchronous subduction of the Chuacús, the formation of HP/HT eclogites within the Chuacús, and the thermal event that reset $\mathrm{Ar}-\mathrm{Ar}$ ages and retrograded the HP/LT assemblages within serpentinites north of the fault were linked. We suggest that fragments of the Mid to Late Cretaceous seafloor (i.e., the Santa Cruz, Juan de Paz, and Baja Vera Paz ophiolites) of the basin that had separated the Chortís and Maya blocks as well as fragments of whatever portions remained of the Farallon plate were obducted onto the Maya block as the Chuacús complex began to underthrust the southern block (Fig. 3B). The southward dip of thrust faults north of the Motagua fault is consistent with this model. The leading edge of the eclogite-bearing Lower Cretaceous accretionary prism was obducted as well. As convergence continued another portion of the Lower Cretaceous HP/LT serpentinite mélange assemblages was re-subducted resulting in the greenschist/amphibolite facies re-metamorphism of the HP/LT eclogites at ca. $70 \mathrm{Ma}$ (Fig. 3B) while the underlying Chuacús complex subducted to even deeper levels to form $\mathrm{HP} / \mathrm{HT}$ eclogites.

\section{Conclusions}

High pressure/low temperature (HP/LT) eclogites within antigoritebearing serpentinite crop out north and south of the Motagua fault, a major strand of the Guatemala suture zone that forms the boundary between the North American and Caribbean plates. The northern association differs from the southern association in petrography, $P-T$ conditions of formation, degree of retrogression, and ${ }^{40} \mathrm{Ar} /{ }^{39} \mathrm{Ar}$ ages. However,
Sm-Nd mineral isochrons from eclogites show that the initial metamorphism that created the eclogites in both terranes occurred at the same time, at ca. 140-120 Ma, probably within the same accretionary system. The Early Cretaceous exhumation of the HP/LT eclogites and associated rocks south of the Motagua fault caused them to be largely unaffected by later events. Those north of the fault, however, were subjected to a subsequent oblique collision at $\sim 70 \mathrm{Ma}$. The disparity between $P$ - T-t records on opposite sides of the fault suggest that the two terranes were separated from each other by a significant lateral distance along the Motagua fault during the Late Cretaceous collision. Their present juxtaposition across a strike slip system means that their positioning occurred since the last oblique collision at $\sim 70 \mathrm{Ma}$. It was most likely produced by left-lateral displacement of the present Chortís block, with its Lower Cretaceous collisional remnants, to its current position adjacent to the Chuacús, although the amount of displacement is unknown. The apparent lack of strike slip displacement based on present surface exposure is therefore deceptive. Serpentinite hosting HP/LT rocks probably occur at depth along much of the modern Guatemala suture zone, but with different $P-T-t$ histories on opposite sides of the Motagua fault. The two presently exposed terranes were exhumed opposite each other by recent uplift resulting from strike slip motion along a restraining bend. Thus the two terranes were juxtaposed at depth by large-scale strike slip motion along the Motagua fault, but their exposure across the fault is due to recent vertical movement and erosion. In summary, our data show that what appears to be a simple terrane boundary defined by serpentinites with HP/LT blocks is not a record of simple continental accretion but rather a more complex record of metamorphic reworking during two oblique collisional events as a 
result of the oblique convergence of the Farallon and North American plates.

The HP/LT metamorphic rocks in the Guatemala suture zone are like beads in a bracelet; they are not only displaced over great distances, but they are also stretched. Rocks similar to the Guatemalan HP/LT rocks occur throughout the Caribbean-North American plate boundary; and can be found eastward to Cuba and the Dominican Republic. The eastwest trending southern Caribbean South American plate boundary is similarly decorated with HP/LT rocks; they have been found from Margarita Island (Venezuela) to Colombia. The oblique evolution model described here for eastern Guatemala appears to be a ubiquitous feature of these two major strike slip terrane boundaries and may apply to similar systems worldwide.

\section{Acknowledgements}

This work was funded by NSF Grants EAR 0309832 to SRH and HKB, EAR0309320 to GEH, and EAR0309116 to HGAL. This project is part of IGCP Project 546 on "Subduction Zones of the Caribbean." We thank Carlos Gonzales for field assistance. We appreciate constructive reviews by Jim Pindell, Sarah Roeske, Taras Gerya, Bradley Hacker and an anonymous reviewer. This contribution is publication number 7265 of Lamont-Doherty Earth Observatory.

\section{Appendix A. Supplementary data}

Supplementary data associated with this article can be found, in the online version, at doi:10.1016/j.epsl.2009.04.032.

\section{References}

Avé Lallemant, H.G., Oldow, J.S., 1988. Early Mesozoic southward migration of Cordilleran transpressional terranes. Tectonics 7, 1057-1075.

Avé Lallemant, H.G., Guth, L.R., 1990. The role of extensional tectonics in exhumation of eclogites and blueschists in an oblique subduction setting: Northeastern Venezuela. Geology 18, 950-953.

Beccaluva, L., Bellia, S., Coltorti, M., Dengo, G., Giunta, G., Mendez, J., Romero, J., Rotolo, S., Siena, F., 1995. The northwestern border of the Caribbean plate in Guatemala: new geological and petrological data on the Motagua ophiolitic belt. Ofioliti 20,1-15.

Chiari, M., Dumitrica, P., Marroni, M., Padolfi, L., Principi, G., 2002. Radiolarian biostratigraphic evidence for a Late Jurassic age of the El Tambor Group ophiolites (Guatemala). Ofioliti 31/2,173-182.

DeMets, C., Mattioli, G., Jansma, P., Rogers, R.D., Tenoria, C., Turner, H.L., 2007. Present motion and deformation of the Caribbean plate: constraints from new GPS geodetic measurements from Honduras and Nicaragua. In: Mann, P. (Ed.), Geologic and tectonic development of the Caribbean plate boundary in northern Central America. Geol. Soc. Amer. Special Paper, 428, pp. 21-36. doi:10.1130/2007.2428(02).

Donnelly, T.W., Home, G.S., Finch, R.C., López -Ramos, E., 1990. Northern Central America; the Maya and Chortis Block. In: Dengo, G., Case, J.E. (Eds.), The Geology of North America. Vol. H. The Caribbean Region: Geol. Soc. Amer. , pp. 37-76.

Edwards, M., Kapos, V., May, I., Ravilious, C., 2000. Mountains and mountain forests, Mesoamerica. UNEP (United Nations Environmental Program) World Conservation Monitoring Centers, U.K. [http://www.unep-wcmc.org/habitats/mountains/cam. html (viewed 10/21/2008)].

Ernst, W.G., 1988. Tectonic history of subduction zones inferred from retrograde blueschist P.T paths. Geology 16, 1081-1084.

Fitch, T.J., 1972. Plate convergence, transcurrent faults, and internal deformation adjacent to Southeast Asia and the western Pacific. J. Geophys. Res. 77, 4432-4469.

Francis, A.H., 2005. Deformation History of the Maya and Chortís Blocks: Insight to the Evolution of the Motagua Fault Zone, Guatemala [MA Thesis]. Houston, Rice University, $149 \mathrm{pp}$.

Francis, A.H., Avé Lallemant, H.G., Sisson, V.B., Harlow, G.E., Donnelly, T.W., Chiquin, M., Roden-Tice, M.K., Hemming, S.R., and Brueckner, H.K., submitted for publication, Two structurally very distinct subduction complexes along the Motagua (Guatemala) suture zone, submitted to the Geol. Soc. of Amer. Bulletin.

Gerya, T.V., Stoeckhert, B., Perchuk, A.L., 2002. Exhumation of high-pressure metamorphic rocks in a subduction channel - a numerical simulation. Tectonics 21/6,1-19.

Giunta, G., Beccaluva, L., Coltorti, M., Cutrupia, D., Mota, B., Padoa, E., Siena, F., Dengo, C., Harlow, G.E., Rosenfeld, J.H., 2002. The Motagua suture zone in Guatemala. Fieldtrip guidebook of the I.B.C.P.-433 Workshop and 2nd Italian-Latin American Geol. Meeting - January 2002. Ofioliti 27, 47-72.

Gorczyk, W., Guillot, S., Gerya, T.V., Hattori, K., 2007. Asthenospheric upwelling, oceanic slab retreat and exhumation of UHP mantle rocks: insights from Greater Antilles. Geophys. Res. Lett. 34, L21309. doi:10.1029/2007GL031059.

Harlow, G.E., Sisson, V.B., Avé Lallemant, H.G., Sorensen, S.S., Seitz, R., 2003. Highpressure, metasomatic rocks along the Motagua fault zone, Guatemala. Ofioliti 28 115-120.
Harlow, G.E., Hemming, S., Avé Lallemant, H., Sisson, V.B., Sorensen, S.S., 2004. Two high-pressure-low-temperature serpentinite-matrix mélange belts, Motagua fault zone, Guatemala: a record of Aptian and Maastrichtian collisions. Geology 32 17-20. doi:10.1130/G19990.1.

Harlow, G.E., Sisson, V.B., Tsujimori, T., Sorensen, S.S., Brueckner, H.K., 2008. P-T conditions of eclogite/garnet-amphibolite from serpentinite mélanges along the Motagua fault zone, Guatemala. Abs. Ann. Meet. Geol. Soc. Amer.: http://a-c-s. confex.com/crops/2008am/webprogram/Paper50090.html.

Hess, H.H., 1965. Mid-oceanic ridges and tectonics, in: submarine geology and geophysics. Proc. 17th Symposium Colston Research Society, pp. 317-334.

Krebs, M., Maresch, W.V., Schertl, H.P., Munker, C., Baumann, A., Draper, G., Idleman, B. Trapp, E., 2008. The dynamics of intra-oceanic subduction zones: a direct comparison between fossil petrological evidence (Rio San Juan complex, Dominican Republic) and numerical simulation. Lithos 103, 106-137.

Maekawa, H., Yamamoto, K., Ueno, T., Osada, Y., Nogami, N., 2004. Significance of serpentinites and related rocks in the high pressure metamorphic terranes, circumPacific regions. In: Ernst, W.G. (Ed.), Serpentinite and Serpentinites: Mineralogy, Petrology, Geochemistry, Ecology, Geophysics, And Tectonics a Tribute to Robert G. Coleman. Geol. Soc. Amer., Internat. Book Series, vol. 8, pp. 167-185.

Mann, P., 2007. Overview of the tectonic history of northern Central America. In: Mann, P. (Ed.), Geologic and tectonic development of the Caribbean plate boundary in northern Central America. Geol. Soc. Amer. Spec. Paper, vol. 428, pp. 1-19. doi:10.1130/2007.2428(02).

Martens, U., Ortega-Obregón, C., Estrada, J., Valle, M., 2007a. Chapter 19, Metamorphism and metamorphic rocks. In: Bundschuh, J., Alvaredo, G.E. (Eds.), Central America: Geology, Resources and Hazards. Taylor and Francis, pp. 489-526. ISBN 9780415416474.

Martens, U., Mattinson, C.G., Wooden, J., Liou, J.G., 2007b. Protolith and metamorphic ages of gneiss hosting eclogite in the Chuacús complex, Central Guatemala. Eos Trans. Amer. Geophys. Union 88(23), Joint Assem. Suppl. Abs. U53A-08.

Martens, U., Mattinson, C., Geldmacher, J., Brueckner, H., Liou, J.G., Wooden, J., 2009. Late Cretaceous continental subduction of North America's southernmost basement. Memorias III Convención Cubana de Ciencias de la Tierra, Havana. Abs.

McBirney, A.R., 1963. Geology of a part of the Central Guatemalan cordillera. Univ. Calif. Pubf. Geol. Sci. 38, 177-242.

McBirney, A.R., Aoki, K.-I., Bass, M., 1967. Eclogites and jadeite from the Motagua fault zone, Guatemala. Am. Mineral. 52, 908-918.

Muller, P.D., 1979. Geology of the Los Amates Quadrangle and Vicinity, Guatemala Central America [Ph.D. Dissertation]. Binghamton, N.Y., State University of New York at Binghamton, $326 \mathrm{pp}$.

Ortega-Gutiérrez, F., Solari, L.A., Solé, J., Martens, U., Gómez-Tuena, A., Morán-Ical, S., Reyes-Salas, M., Ortega-Obregón, C., 2004. Polyphase, high-temperature eclogitefacies metamorphism in the Chuacús complex, central Guatemala: petrology geochronology and tectonic implications. Int. Geol. Rev. 46, 445-470.

Ortega-Gutiérez, F., Solari, L.A., Ortega-Obregón, C., Elías-Herrera, M., Martens, U., Morán-Icál, S., Chiquín, M., Keppy, J.D., Torres de León, R., Schaaf, P., 2007. The MayaChortís boundary: a tectonostratigraphic approach. Int. Geol. Rev. 49, 996-1024.

Pindell, J.L., 1994. Evolution of the Gulf of Mexico and Caribbean. In: Donovan, S.K., Jackson, T.A. (Eds.), Caribbean Geology: An Introduction. Kingston, Jamaica University of West Indies Publishers' Association, pp. 13-39.

Pindell, J., Kennan, L., in press. Tectonic Evolution of the Gulf of Mexico, Caribbean and Northern South America in the Mantle Reference Frame: an Update. In: Pindell, J., Kennan, L. (Eds.), The Geology and Evolution of the Region between North and South America. Geol. Soc. London, Special Publications. doi:10.1144/SP328.1.

Rogers, R.D., Mann, P., 2007. Transtensional deformation of the western CaribbeanNorth America plate boundary zone. In: Mann, P. (Ed.), Geologic and Tectonic Development of the Caribbean Plate Boundary in northern Central America. Geol. Soc. Amer. Special Paper, vol. 428, pp. 37-64. doi:10.1130/2007.2428(02).

Rogers, R.D., Karason, H., van der Hilst, R., 2002. Epeirogenic uplift above a detached slab in northern Central America. Geology 30, 1031-1034.

Rosencrantz, E., Mann, P., 1991. SeaMARC II mapping of transform faults in the Cayman Trough, Caribbean Sea. Geology 19, 690-693.

Rosenfeld, J.H., 1981. Geology of the Western Sierra de Santa Cruz, Guatemala, Central America: An Ophiolite Sequence [Ph.D. Thesis]. Binghamton, State University of New York at Binghamton, 313 pp.

Schwartz, D.P., Cluff, L.S., Donnelley, T.W., 1979. Quaternary faulting along the Caribbean-North American Plate Boundary in Central America. Tectonophysics 52, 431-445.

Simons, K.K., Harlow, G.E., Brueckner, H.K., Goldstein, S.L., Sorensen, S.S., Hemming, N.G., Langmuir, C.H., submitted for publication. Lithium isotopes in Guatemala and Franciscan HP-LT rocks: insights into the role of sediment-derived fluids in the mantle wedge. Geochim. Cosmochim. Acta.

Scholl, D.W., von Huene, R., 2007. Crustal recycling at modern subduction zones applied to the past-issues of growth and preservation of continental basement crust, mantle geochemistry, and supercontinent reconstruction. In: Hatcher Jr., R.D. Carlsen, M.P., McBride, J.H., Martínez-Catalán, J.R. (Eds.), 4-D Framework of Continental Crust. Geol. Soc. Amer. Memoir, vol. 200, pp. 9-32.

Sorensen, S., Harlow, G.E., Rumble, D., 2006. The origin of jadeitite-forming subduction zone fluids: CL-guided SIMS oxygen isotope and trace element evidence. Am. Mineral. 91, 979-996.

Tsujimori, T., Liou, J.G., Coleman, R.G., 2004. Comparison of two contrasting eclogites from the Motagua fault zone, Guatemala: Southern lawsonite eclogite versus northern zoisite eclogite. Abs. Geol. Soc. Amer. 36 (5), 136.

Tsujimori, T., Liou, J.G., Coleman, R.G., 2005. Coexisting retrograde jadeite and omphacite in a jadeite-bearing lawsonite eclogite from the Motagua fault zone, Guatemala. Am. Mineral. 90, 836-842. 
Tsujimori, T., Sisson, V.B., Liou, J.G., Harlow, G.E., Sorensen, S.S., 2006a. Petrologic characterization of Guatemalan lawsonite-eclogite: direct information on eclogitization of subducted oceanic crust in a cold subduction zone. In: Hacker, B.H. McClelland, W.C., Liou, J.G. (Eds.), Ultrahigh-Pressure Metamorphism: Deep Continental Subduction. Geol. Soc. Amer. Special Paper, vol. 403, pp. 147-168.

Tsujimori, T., Sisson, V.B., Liou, J.G., Harlow, G.E., Sorensen, S.S., 2006b. Very lowtemperature record in subduction process: a review of global lawsonite-eclogites. Lithos 92, 609-624. doi:10.1016/j.lithos.2006.03.054.
Umhoefer, P.J., Dorsey, R.J., 1997. Translations of terranes; lessons from central Baja California, Mexico. Geology 25, 1007-1010.

von Huene, R., Ramero, C.R., Vannucchi, P., 2004. Generic model of subduction erosion. Geology 32, 913-916.

Wilson, J.T., 1960. Did the Atlantic close and then re-open? Nature 211, 676-681. 